\title{
Solvothermal synthesis and theoretical study of a polypyridium trimesylate adduct
}

\author{
YULAN ZHU ${ }^{\mathrm{a}, \mathrm{b}, *}$, FENG MA ${ }^{\mathrm{a}, \mathrm{b}}$, KUIRONG MA ${ }^{\mathrm{a}}$, LI CAO ${ }^{\mathrm{a}}$ and LIANHUA ZHAO \\ a Jiangsu Key Laboratory for Chemistry of Low-dimensional Materials, School of Chemistry \\ and Chemical Engineering, Huaiyin Normal University, Huai' an 223300, P R China \\ ${ }^{b}$ Department of Chemistry, Science College, Yanbian University, Yanji 133002, P R China \\ e-mail: yulanzhu2008@126.com
}

MS received 6 December 2010; accepted 17 May 2011

\begin{abstract}
The title compound $\left(\mathrm{C}_{9} \mathrm{H}_{3} \mathrm{O}_{6} \cdot \mathrm{C}_{20} \mathrm{H}_{17} \mathrm{~N}_{4}\right)_{4} \cdot 0.5 \mathrm{H}_{2} \mathrm{O} 1$ was isolated from solvothermal synthesis of $4^{\prime}$-(4-pyridyl)-2,2':6',2'-terpyridine (pytpy) and trimesic acid (1,3,5-benzenetricarboxylic acid, $\mathrm{H}_{3} \mathrm{BTC}$ ). It was characterized by element analysis, IR, TGA, XRD, X-ray single-crystal diffraction, and spectroscopy properties, together with quantum chemistry calculation of spectrum (UV-vis spectra) through the method b3lyp/6-31 $\operatorname{tg}(\mathrm{d}, \mathrm{p})$ are also investigated. Single-crystal X-ray diffraction shows 1 possesses a 3-D supramolecular network with 1-D six-fold helical double chains built from protonated $\left(\mathrm{H}_{3} \text { pytpy }\right)_{n}^{3+}$ cations and deprotonated (BTC ${ }_{n}^{3-}$ anions. The maximum of the fluorescent emission bands of $\mathbf{1}$ is located at $427 \mathrm{~nm}\left(\lambda_{\mathrm{ex}}=266 \mathrm{~nm}\right)$, with a shoulder at about $390 \mathrm{~nm}$. The result of theoretic calculations confirms that 1 has small HOMO-LUMO energy gap $(1.24 \mathrm{eV})$ and high chemical reactivity.
\end{abstract}

Keywords. $\quad N$-heterocyclic adduct; solvothermal synthesis; spectroscopy; DFT.

\section{Introduction}

$4^{\prime}$-(4-Pyridyl)-2,2' $: 6^{\prime}, 2^{\prime}$-terpyridine (pytpy) ${ }^{1-5}$ is a derivative from pyridyl-donor ligands, such as pyrazine ${ }^{6}$ and $4,4^{\prime}$-bipyridine. ${ }^{7}$ The $2,2^{\prime}: 6^{\prime}, 2^{\prime}$-terpyridine (terpy) substituent presents interesting electronic, photonic and magnetic properties when coordinating to transition metal. ${ }^{8,9}$ Substituted pyridines including $4^{\prime}$-(4pyridyl)-2, $2^{\prime}: 6^{\prime}, 2^{\prime}$-terpyridine are prominent building blocks in both organic and inorganic supramolecular chemistry because of their $\pi$-stacking ability, directional $\mathrm{H}$-bonding and coordination properties. ${ }^{10}$ Pytpy is also a member of the polypyridyl. Polypyridyl compounds have been extensively researched because of substantial interest in their fascinating structures with potential applications in fields such as the life sciences, clinical medicine, and material chemistry. ${ }^{11-14}$ Many compounds containing pytpy have been reported, however, its integrated result incorporating with trimesic acid have been rarely investigated to date. ${ }^{15,16}$ Benzene-1,3,5-tricarboxylic acid $\left(\mathrm{H}_{3} \mathrm{BTC}\right)$ is widely used as building blocks due to its versatile coordination modes, rigidity and potential ability for the construction of hydrogen bonds. ${ }^{17}$ This molecule predictably forms hydrogen-bonded net-

*For correspondence works when linking to other molecules, such as $\mathrm{N}$ heterocyclic molecules. In this paper, we recommend a new adduct of $4^{\prime}$-(4-pyridyl)-2,2':6',2'-terpyridine (pytpy) and 1,3,5-benzenetricarboxylic acid $\left(\mathrm{H}_{3} \mathrm{BTC}\right)$, $\left(\mathrm{C}_{9} \mathrm{H}_{3} \mathrm{O}_{6} \cdot \mathrm{C}_{20} \mathrm{H}_{17} \mathrm{~N}_{4}\right)_{4} \cdot 0.5 \mathrm{H}_{2} \mathrm{O} \mathrm{1}$, in which there are lots of hydrogen bonds and $\pi-\pi$ interactions. A series of physical methods like UV-vis absorption, fluorescence measurements have been used to probe the interactions between pytpy and $\mathrm{H}_{3} \mathrm{BTC}$. The spectrum (UVvis spectra) of $\mathbf{1}$ is investigated to have a better understanding on the electron-donor properties. Also we performed the single-point calculations at DFT/B3LYP/6$31 \mathrm{t} \mathrm{g}(\mathrm{d}, \mathrm{p})$ level ${ }^{18,19}$ on the neutral 1, starting from the experimental X-ray structures as input geometries and employing the Gaussian 03 program package. ${ }^{20}$ The result of theoretic calculations indicates that $\mathbf{1}$ has small HOMO-LUMO energy gap $(1.24 \mathrm{eV})$ and high chemical reactivity. In the next step, we will attempt to design and synthesize compound contains rare earth metal ions and $\mathbf{1}$.

\section{Experimental}

\subsection{Materials and physical measurements}

All reagents were purchased from commercial sources and used without further purification. Element analyses 
were performed on a Perkin-Elmer 2400LS elemental analyzer. IR spectra were recorded from 4000 to $400 \mathrm{~cm}^{-1}$ with a Nicolet AVATAR360 instrument. The thermal gravimetric analyses (TGA) were carried out with a TGA/SDTA851e differential thermal analyzer with a heating rate of $10^{\circ} \mathrm{C} / \mathrm{min}$. Powder X-ray diffraction patterns were performed on an ARL X'TRA diffractometer using $\mathrm{Cu}-\mathrm{K} \alpha$ radiation. The absorption spectra were recorded on an Australia GBC UV/Vis 916 spectrophotometer in the range of $200-700 \mathrm{~nm}$. Emission spectra in the solid state at room temperature were taken on a Perkin-Elmer LS-55 fluorescence spectrophotometer.

\subsection{Synthesis of the Compound $\mathbf{1}$}

The mixture of pytpy $(0.3 \mathrm{mmol}, 0.063 \mathrm{~g}), \mathrm{H}_{3} \mathrm{BTC}$ $(0.1 \mathrm{mmol}, 0.021 \mathrm{~g})$ and ethanol $(5 \mathrm{~mL})$ was stirred for $30 \mathrm{~min}$ in the presence of $\mathrm{Fe}^{2+}(0.2 \mathrm{mmol})$, and sealed into a $20 \mathrm{~mL}$ Teflon-lined reactor. Solution was heated to $120^{\circ} \mathrm{C}$ for 6 days, and then cooled to room temperature. The crystalline of $\mathbf{1}$ (yellow block) was collected by vacuum filtration, washed thoroughly with ethanol and dried in air (yield $62 \%$ based on $\mathrm{H}_{3} \mathrm{BTC}$ ). Elemental analysis $\left(\mathrm{C}_{9} \mathrm{H}_{3} \mathrm{O}_{6} \cdot \mathrm{C}_{20} \mathrm{H}_{17} \mathrm{~N}_{4}\right)_{4} \cdot 0.5 \mathrm{H}_{2} \mathrm{O}$ : Calcd. $\mathrm{C}$ 63.84, H 4.06, N 11.24; Found C 63.54, H 3.91, N 11.12. IR (KBr, cm $\left.{ }^{-1}\right): 3423(\mathrm{~m}), 3103(\mathrm{~m}), 2477(\mathrm{w})$, 1901(w), 1707 (s), 1605 (w), 1524(s), 1400(m), 1368 (m), $1258(\mathrm{~s}), 1212(\mathrm{~m}), 1097(\mathrm{~m}), 1060(\mathrm{~m}), 1018(\mathrm{~m})$, $828(\mathrm{w}), 780(\mathrm{w}), 667(\mathrm{~m}), 638(\mathrm{~m})$.

\section{$2.3 X$-ray crystallography}

A single crystal of $\mathbf{1}$ was mounted on a Rigaku R-AXIS RAPID IP diffractometer equipped with graphitemonochromated Mo-K $\alpha$ radiation $(0.71073 \AA$ ). Intensity data were collected at $293 \pm 2 \mathrm{~K}$ and processed on a $P C$ with the SAINT Plus software package. Structure was solved by direct methods and refined by fullmatrix leastsquares fitting on $F^{2}$ by SHELXTL97 ${ }^{21}$ software. All non-hydrogen atoms of $\mathbf{1}$ were refined with anisotropic thermal parameters. The positions of hydrogen atoms were located by calculating geometrically. CCDC No.777270 contains the supplementary crystallographic data for the compound $\mathbf{1}$. These data can be obtained free of charge from The Cambridge Crystallographic Data Centre via www.ccdc.cam.ac. uk/data_request/cif.

\subsection{Quantum chemistry calculation method}

To have a better understanding on the electron-donor properties of $\mathbf{1}$, we performed the single-point calcu- lations at DFT/B3LYP/6-31 t g (d,p) level on the neutral 1, starting from the experimental $\mathrm{X}$-ray structures as input geometries, employing the Gaussian 03 program package. To investigate the nature of electronic transitions, the electronic spectra of $\mathbf{1}$ was calculated using the time-dependent DFT (TDDFT) approach at the B3LYP/6-31G* level.

\section{Results and discussion}

\subsection{Description of structure}

Single-crystal XRD analysis reveals the asymmetric unit of 1 contains one protonated $\mathrm{H}_{3}$ pytpy ${ }^{3+}$ cation, one deprotonated $\mathrm{BTC}^{3-}$ anion and one dissociative water molecule (figure 1, table 1). Based on coordination environment and charge balance, the $\mathrm{H}_{3} \mathrm{BTC}$ should be fully deprotonated, but the nitrogen atoms $\mathrm{N}(1), \mathrm{N}(2)$ and $\mathrm{N}(4)$ of pytpy are protonated as $\mathrm{H}_{3}$ pytpy ${ }^{3+}$, corresponding one band at $3423 \mathrm{~cm}^{-1}(\mathrm{~N}-\mathrm{H})$ in IR spectrum. In 1, the $\mathrm{C}(17)-\mathrm{N}(1), \mathrm{C}(18)-\mathrm{N}(1), \mathrm{C}(4)-\mathrm{N}(2), \mathrm{C}(1)$ $\mathrm{N}(2), \mathrm{C}(5)-\mathrm{N}(3), \mathrm{C}(9)-\mathrm{N}(3), \mathrm{C}(10)-\mathrm{N}(4), \mathrm{C}(14)-\mathrm{N}(4)$ are 1.324(5) $\AA, 1.323(5) \AA, 1.388(5) \AA, 1.366(5) \AA$, 1.339(4) $\AA, 1.345(4) \AA, 1.375(5) \AA$ and 1.360(5) $\AA$, respectively. These bond distances are shorter enough than the sum of Van der Waals radii between $\mathrm{C}$ atom and $\mathrm{N}$ atom, $\mathrm{C}-\mathrm{N}$ bonds $(1.47-1.50 \AA)$. The exocyclic bond lengths $\mathrm{C}(4)-\mathrm{C}(5), \mathrm{C}(9)-\mathrm{C}(10)$ and $\mathrm{C}(7)-\mathrm{C}(15)$ are elongated to $1.489(5) \AA, 1.493(5) \AA$ and $1.498(5)$ $\AA$, longer than the cyclic those of $\mathrm{C}-\mathrm{C}$ bonds (average
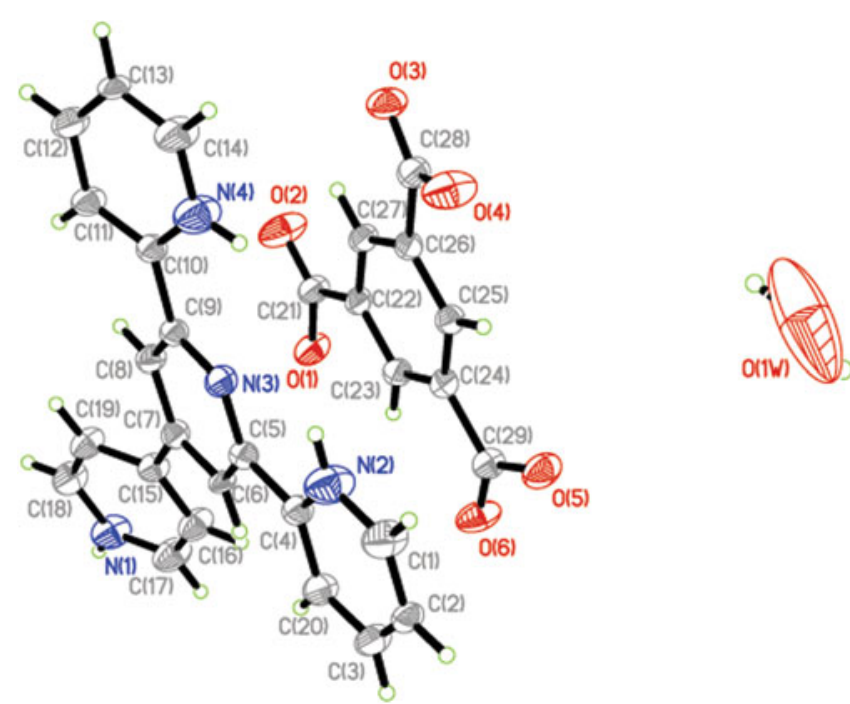

Figure 1. ORTEP view of $\mathbf{1}$ showing the atom-labelling scheme (50\% thermal ellipsoids). 
Table 1. Crystallographic data for $\mathbf{1}$.

\begin{tabular}{ll}
\hline Parameters & $\mathbf{1}$ \\
\hline Empirical formula & $\mathrm{C}_{58} \mathrm{H}_{40.50} \mathrm{~N}_{8} \mathrm{O}_{12.25}$ \\
Formula weight & 1045.48 \\
Temperature & $296(2) \mathrm{K}$ \\
Wavelength & $0.71073 \AA$ \\
Crystal system & Monoclinic \\
Space group & $C_{2} / c$ \\
Unit cell dimensions & $a=26.205(4) \AA$ \\
& $b=13.612(2) \AA$ \\
& $c=17.899(3) \AA$ \\
& $\beta=109.699(2)^{\circ}$ \\
Volume & $6011.0(2) \AA^{3}$ \\
$Z$ & 4 \\
Calculated density & $1.155 \mathrm{Mg} / \mathrm{m}^{3}$ \\
Absorption coefficient & $0.083 \mathrm{~mm}{ }^{-1}$ \\
F(000) & 2170 \\
Theta range for data collection & $1.93^{\circ}-25.00^{\circ}$ \\
Limiting indices & $-31 \leq h \leq 31,-16 \leq k \leq 13,-21 \leq l \leq 21$ \\
Reflections collected/unique & $20069 / 5148[R($ int $)=0.0547]$ \\
Completeness to theta $=25.00$ & $97.1 \%$ \\
Refinement method & Full-matrix least-squares on $F^{2}$ \\
Data/restraints/parameters & $5148 / 2 / 358$ \\
Goodness-of-fit on $F^{2}$ & 1.081 \\
Final $R$ indices $[I>2$ sigma $(I)]$ & $R_{1}=0.0847, w R_{2}=0.2406$ \\
$R$ indices (all data) & $R_{1}=0.1241, w R_{2}=0.2776$ \\
Largest diff. peak and hole & 0.500 and -0.463 e. $\AA^{-3}$ \\
\hline
\end{tabular}

$1.388 \AA$ A). Meanwhile, the pendant pyridine ring (N(1)$\mathrm{C}(17)-\mathrm{C}(16)-\mathrm{C}(15)-\mathrm{C}(19)-\mathrm{C}(18))$ and $(\mathrm{N}(4)-\mathrm{C}(10)-$ $\mathrm{C}(11)-\mathrm{C}(12)-\mathrm{C}(13)-\mathrm{C}(14))$ are twisted with respect to the central ring $(\mathrm{N}(3)-\mathrm{C}(5)-\mathrm{C}(6)-\mathrm{C}(7)-\mathrm{C}(8)-\mathrm{C}(9))$ of each terpy domain of $\mathrm{H}_{3}$ pytpy ${ }^{3+}$ (dihedral angles: $23.64^{\circ}$ and $17.36^{\circ}$ ). This induces the disappearance of face-to-face or edge-to-face interactions between pendant pyridine rings containing $\mathrm{N}(1)$ and $\mathrm{N}(4)$ atoms, respectively, and terpy rings.

The bond lengths of $\mathrm{C}-\mathrm{O}$ are different from each other and the $\mathrm{C}(29)-\mathrm{O}(5)$ (1.331(4) $\AA$ ), $\mathrm{C}(21)-\mathrm{O}(1)$ $(1.306(4) \AA), C(28)-\mathrm{O}(4)(1.315(4) \AA)$ are much longer than the $\mathrm{C}(29)-\mathrm{O}(6)(1.197(4) \AA), \mathrm{C}(21)-\mathrm{O}(2)$ $(1.205(4) \AA), \mathrm{C}(28)-\mathrm{O}(3)(1.213(4) \AA)$ in the carboxyl groups. So C(29)-O(6), C(21)-O(2) and C(28)$\mathrm{O}(3)$ can be assigned as double bonds, and $\mathrm{C}(29)$ $\mathrm{O}(5), \mathrm{C}(21)-\mathrm{O}(1)$ and $\mathrm{C}(28)-\mathrm{O}(3)$ as single bonds. One carboxylate group $(\mathrm{O}(3)-\mathrm{C}(28)-\mathrm{O}(4))$ is twisted with respect to the central benzene ring $(\mathrm{C}(22)-\mathrm{C}(23)-$ $\mathrm{C}(24)-\mathrm{C}(25)-\mathrm{C}(26)-\mathrm{C}(27))$ in $\mathrm{BTC}^{3-}$ (dihedral angle $10.39^{\circ}$ ), which induces the disappearance of hydrogen bond interactions between $\mathrm{H}_{3}$ pytpy ${ }^{3+}$ and $\mathrm{O}(3)$ of $\mathrm{BTC}^{3-}$. Selected bond lengths and angles for $\mathbf{1}$ are listed in table 2.
Seven hydrogen bonds are shown in figure 2 (table 3 ). Along the $b$-axis, $\mathrm{H}_{3}$ pytpy ${ }^{3+}$ and $\mathrm{BTC}^{3-}$ are connected with each other by hydrogen bonds, $\mathrm{C}(13)-\mathrm{H}(13 \mathrm{~A}) \ldots$ $\mathrm{O}(1)\left(2.619 \AA, 160.0^{\circ}\right), \mathrm{C}(14)-\mathrm{H}(20) \cdots \mathrm{O}(2)(3.165 \AA$, $\left.131.0^{\circ}\right), \mathrm{N}(1)-\mathrm{H}(1 \mathrm{~A}) \cdots \mathrm{O}(4)\left(2.618 \AA, 158.8^{\circ}\right)$, to extend into a single helical chain (figure $3 a$ ). Six adjacent single helical chains are joined together to lead to an unique six-fold helical chain by hydrogen bonds, $\mathrm{C}(18)-\mathrm{H}(3) \cdots \mathrm{O}(2)\left(3.389 \AA, 168.0^{\circ}\right)$, $\mathrm{C}(11)-\mathrm{H}(17) \cdots \mathrm{O}(6) \quad\left(3.184 \AA, 123.0^{\circ}\right)$, and $\pi-\pi$ interactions in offset face-to-face between the sixmembered ring $(\mathrm{N}(3)-\mathrm{C}(5)-\mathrm{C}(6)-\mathrm{C}(7)-\mathrm{C}(8)-\mathrm{C}(9))$ and the six-membered ring $(\mathrm{C}(22)-\mathrm{C}(23)-\mathrm{C}(24)-\mathrm{C}(25)-$ $\mathrm{C}(26)-\mathrm{C}(27)$ ) (centroidal distance $3.730 \AA$, and dihedral angle $2.82^{\circ}$ ), as well $\pi-\pi$ interactions in face-toface between two benzene rings (centroidal distance $3.590 \AA$ A). Two neighbouring 1-D six-fold helical chains interact with each other to give rise to a double six-fold helical chain down the $b$-axis by the $\pi-\pi$ interactions in an offset face-to-face arrangement between the sixmembered ring $(\mathrm{N}(2)-\mathrm{C}(1)-\mathrm{C}(2)-\mathrm{C}(3)-\mathrm{C}(20)-\mathrm{C}(4))$ and the six-membered ring $(\mathrm{N}(3)-\mathrm{C}(5)-\mathrm{C}(6)-\mathrm{C}(7)-$ $\mathrm{C}(8)-\mathrm{C}(9))$ (centroidal distance $3.725 \AA$, and the dihedral angle $3.54^{\circ}$ ), which is further extended into a 2-D 
Table 2. Selected bond lengths $[\AA]$ and angles $\left[{ }^{\circ}\right]$ for $\mathbf{1}$.

\begin{tabular}{|c|c|c|c|}
\hline \multicolumn{4}{|l|}{ Bond lengths } \\
\hline $\mathrm{C}(1)-\mathrm{C}(2)$ & $1.326(5)$ & $\mathrm{C}(14)-\mathrm{N}(4)$ & $1.360(5)$ \\
\hline $\mathrm{C}(1)-\mathrm{N}(2)$ & $1.366(5)$ & $C(15)-C(16)$ & $1.358(5)$ \\
\hline$C(2)-C(3)$ & $1.337(6)$ & $C(15)-C(19)$ & $1.395(5)$ \\
\hline $\mathrm{C}(3)-\mathrm{C}(20)$ & $1.358(5)$ & $C(16)-C(17)$ & $1.380(6)$ \\
\hline$C(4)-C(20)$ & $1.387(5)$ & $\mathrm{C}(17)-\mathrm{N}(1)$ & $1.324(5)$ \\
\hline $\mathrm{C}(4)-\mathrm{N}(2)$ & $1.388(5)$ & $\mathrm{C}(18)-\mathrm{N}(1)$ & $1.323(5)$ \\
\hline$C(4)-C(5)$ & $1.489(5)$ & $\mathrm{C}(18)-\mathrm{C}(19)$ & $1.385(5)$ \\
\hline$C(5)-C(6)$ & $1.319(4)$ & $\mathrm{C}(21)-\mathrm{O}(2)$ & $1.205(4)$ \\
\hline $\mathrm{C}(5)-\mathrm{N}(3)$ & $1.339(4)$ & $\mathrm{C}(21)-\mathrm{O}(1)$ & $1.306(4)$ \\
\hline $\mathrm{C}(6)-\mathrm{C}(7)$ & $1.344(4)$ & $\mathrm{C}(21)-\mathrm{C}(22)$ & $1.483(5)$ \\
\hline $\mathrm{C}(7)-\mathrm{C}(8)$ & $1.388(5)$ & $\mathrm{C}(22)-\mathrm{C}(27)$ & $1.379(5)$ \\
\hline$C(7)-C(15)$ & $1.498(5)$ & $\mathrm{C}(22)-\mathrm{C}(23)$ & $1.386(5)$ \\
\hline $\mathrm{C}(8)-\mathrm{C}(9)$ & $1.378(5)$ & $C(23)-C(24)$ & $1.384(5)$ \\
\hline $\mathrm{C}(9)-\mathrm{N}(3)$ & $1.345(4)$ & $\mathrm{C}(24)-\mathrm{C}(25)$ & $1.386(5)$ \\
\hline$C(9)-C(10)$ & $1.493(5)$ & $\mathrm{C}(24)-\mathrm{C}(29)$ & $1.503(5)$ \\
\hline $\mathrm{C}(10)-\mathrm{N}(4)$ & $1.375(5)$ & $C(25)-C(26)$ & $1.388(5)$ \\
\hline $\mathrm{C}(10)-\mathrm{C}(11)$ & $1.379(5)$ & $C(26)-C(27)$ & $1.392(5)$ \\
\hline $\mathrm{C}(11)-\mathrm{C}(12)$ & $1.374(5)$ & $C(26)-C(28)$ & $1.479(5)$ \\
\hline $\mathrm{C}(12)-\mathrm{C}(13)$ & $1.343(5)$ & $\mathrm{C}(28)-\mathrm{O}(3)$ & $1.213(4)$ \\
\hline $\mathrm{C}(13)-\mathrm{C}(14)$ & $1.330(5)$ & $\mathrm{C}(28)-\mathrm{O}(4)$ & $1.315(4)$ \\
\hline $\mathrm{C}(29)-\mathrm{O}(6)$ & $1.197(4)$ & $\mathrm{C}(29)-\mathrm{O}(5)$ & $1.331(4)$ \\
\hline \multicolumn{4}{|l|}{ Bond angles } \\
\hline $\mathrm{C}(2)-\mathrm{C}(1)-\mathrm{N}(2)$ & $123.2(4)$ & $\mathrm{N}(4)-\mathrm{C}(10)-\mathrm{C}(9)$ & $119.5(3)$ \\
\hline $\mathrm{C}(1)-\mathrm{C}(2)-\mathrm{C}(3)$ & $117.3(3)$ & $\mathrm{C}(11)-\mathrm{C}(10)-\mathrm{C}(9)$ & $122.7(3)$ \\
\hline $\mathrm{C}(2)-\mathrm{C}(3)-\mathrm{C}(20)$ & $123.4(4)$ & $\mathrm{C}(12)-\mathrm{C}(11)-\mathrm{C}(10)$ & $119.2(3)$ \\
\hline $\mathrm{C}(20)-\mathrm{C}(4)-\mathrm{N}(2)$ & $116.8(3)$ & $\mathrm{C}(13)-\mathrm{C}(12)-\mathrm{C}(11)$ & $122.3(4)$ \\
\hline$C(20)-C(4)-C(5)$ & $121.1(3)$ & $\mathrm{C}(14)-\mathrm{C}(13)-\mathrm{C}(12)$ & $117.9(3)$ \\
\hline $\mathrm{N}(2)-\mathrm{C}(4)-\mathrm{C}(5)$ & $122.0(3)$ & $\mathrm{C}(13)-\mathrm{C}(14)-\mathrm{N}(4)$ & $122.7(4)$ \\
\hline $\mathrm{C}(6)-\mathrm{C}(5)-\mathrm{N}(3)$ & $125.3(3)$ & $C(16)-C(15)-C(19)$ & $118.1(3)$ \\
\hline$C(6)-C(5)-C(4)$ & $118.7(3)$ & $\mathrm{C}(16)-\mathrm{C}(15)-\mathrm{C}(7)$ & $120.6(3)$ \\
\hline $\mathrm{N}(3)-\mathrm{C}(5)-\mathrm{C}(4)$ & $116.0(3)$ & $\mathrm{C}(19)-\mathrm{C}(15)-\mathrm{C}(7)$ & $121.2(3)$ \\
\hline$C(5)-C(6)-C(7)$ & $118.1(3)$ & $\mathrm{C}(15)-\mathrm{C}(16)-\mathrm{C}(17)$ & $119.7(4)$ \\
\hline $\mathrm{C}(6)-\mathrm{C}(7)-\mathrm{C}(8)$ & $120.5(3)$ & $\mathrm{N}(1)-\mathrm{C}(17)-\mathrm{C}(16)$ & $122.6(4)$ \\
\hline$C(6)-C(7)-C(15)$ & $115.9(3)$ & $\mathrm{N}(1)-\mathrm{C}(18)-\mathrm{C}(19)$ & $122.7(4)$ \\
\hline$C(8)-C(7)-C(15)$ & $123.6(3)$ & $\mathrm{C}(18)-\mathrm{C}(19)-\mathrm{C}(15)$ & $118.5(4)$ \\
\hline $\mathrm{C}(9)-\mathrm{C}(8)-\mathrm{C}(7)$ & $117.8(3)$ & $\mathrm{C}(3)-\mathrm{C}(20)-\mathrm{C}(4)$ & $119.7(4)$ \\
\hline $\mathrm{N}(3)-\mathrm{C}(9)-\mathrm{C}(8)$ & $121.4(3)$ & $\mathrm{O}(2)-\mathrm{C}(21)-\mathrm{O}(1)$ & $123.0(3)$ \\
\hline $\mathrm{N}(3)-\mathrm{C}(9)-\mathrm{C}(10)$ & $114.9(3)$ & $\mathrm{O}(2)-\mathrm{C}(21)-\mathrm{C}(22)$ & $121.9(3)$ \\
\hline C(8)-C(9)-C(10) & $123.6(3)$ & $\mathrm{O}(1)-\mathrm{C}(21)-\mathrm{C}(22)$ & $115.1(3)$ \\
\hline $\mathrm{N}(4)-\mathrm{C}(10)-\mathrm{C}(11)$ & $117.9(3)$ & $C(27)-C(22)-C(23)$ & $119.4(3)$ \\
\hline $\mathrm{C}(23)-\mathrm{C}(24)-\mathrm{C}(25)$ & $119.8(3)$ & $\mathrm{C}(27)-\mathrm{C}(22)-\mathrm{C}(21)$ & $119.7(3)$ \\
\hline$C(23)-C(24)-C(29)$ & $116.5(3)$ & $\mathrm{C}(23)-\mathrm{C}(22)-\mathrm{C}(21)$ & $120.9(3)$ \\
\hline $\mathrm{C}(25)-\mathrm{C}(24)-\mathrm{C}(29)$ & $123.7(3)$ & $\mathrm{C}(24)-\mathrm{C}(23)-\mathrm{C}(22)$ & $120.4(3)$ \\
\hline$C(24)-C(25)-C(26)$ & $120.5(3)$ & $\mathrm{O}(3)-\mathrm{C}(28)-\mathrm{C}(26)$ & $124.0(3)$ \\
\hline$C(25)-C(26)-C(27)$ & $118.9(3)$ & $\mathrm{O}(4)-\mathrm{C}(28)-\mathrm{C}(26)$ & $113.5(3)$ \\
\hline $\mathrm{C}(25)-\mathrm{C}(26)-\mathrm{C}(28)$ & $121.9(3)$ & $\mathrm{O}(6)-\mathrm{C}(29)-\mathrm{O}(5)$ & $122.7(3)$ \\
\hline$C(27)-C(26)-C(28)$ & $119.2(3)$ & $\mathrm{O}(6)-\mathrm{C}(29)-\mathrm{C}(24)$ & $123.0(3)$ \\
\hline $\mathrm{C}(22)-\mathrm{C}(27)-\mathrm{C}(26)$ & $121.0(3)$ & $\mathrm{O}(5)-\mathrm{C}(29)-\mathrm{C}(24)$ & $114.2(3)$ \\
\hline $\mathrm{O}(3)-\mathrm{C}(28)-\mathrm{O}(4)$ & $122.5(3)$ & $\mathrm{C}(5)-\mathrm{N}(3)-\mathrm{C}(9)$ & $116.9(3)$ \\
\hline $\mathrm{C}(18)-\mathrm{N}(1)-\mathrm{C}(17)$ & $118.4(3)$ & $\mathrm{C}(14)-\mathrm{N}(4)-\mathrm{C}(10)$ & $120.0(4)$ \\
\hline $\mathrm{C}(1)-\mathrm{N}(2)-\mathrm{C}(4)$ & $119.7(4)$ & & \\
\hline
\end{tabular}

sixfold helical layer in the $a b$ plane (figure $3 \mathrm{~b}$ ). At last, a 3-D supramolecular network with cavities is obtained built from 2-D helical layers packing along the $c-$ axis via hydrogen bonds $\mathrm{C}(2)-\mathrm{H}(14) \cdots \mathrm{O}(5)(2.685 \AA$, 


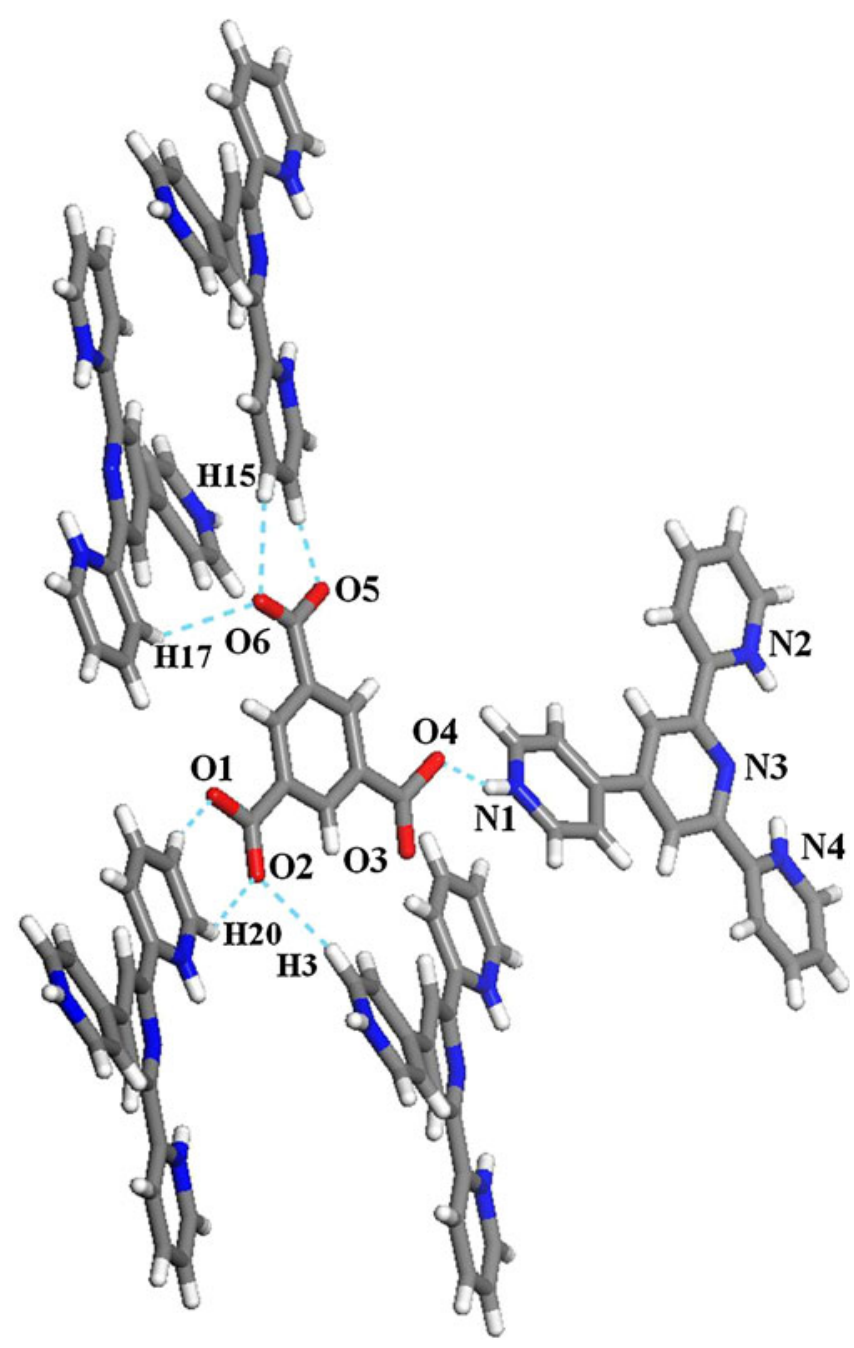

Figure 2. Seven hydrogen bonds in 1, hydrogen bonds are drawn as dotted light blue lines. Colour code: $\mathrm{C}$, gray; $\mathrm{N}$, blue; $\mathrm{O}$, red; $\mathrm{H}$, white.

$\left.168.0^{\circ}\right)$ and $\mathrm{C}(3)-\mathrm{H}(15) \cdots \mathrm{O}(6)\left(3.132 \AA, 127.0^{\circ}\right)$, and the dissociative water molecules are located between the helical layers (figure 4). All the hydrogen bonds and $\pi-\pi$ interactions are best propitious to stabilize the structure, as well as charge transfer. As a continuous work, we now attempt to combine rare earth metal ions with adduct $\mathbf{1}$ to investigate their unanticipated properties.

\subsection{XRD and thermal analysis}

In order to check the phase purity, the XRD patterns of the compound 1 were checked at room temperature. The peak positions of the simulated and experimental XRD patterns are in agreement with each other, demonstrating the good phase purity of the compound (figure 5).

The thermal stability of $\mathbf{1}$ was investigated by the TG-DTA analysis experiments (figure 6). The first mass loss of $0.52 \%$ from $70^{\circ} \mathrm{C}$ to $120^{\circ} \mathrm{C}$, with an endothermic peak centered at $90^{\circ} \mathrm{C}$, corresponds to the loss of one lattice water molecule (Calcd. $0.43 \%$ ). From $300^{\circ} \mathrm{C}$ to $500^{\circ} \mathrm{C}$, the DTA curve shows a weaker endothermic peak at $348^{\circ} \mathrm{C}$ and a stronger exothermic peak at $430^{\circ} \mathrm{C}$, and the corresponding TGA curve shows two weight losses in this temperature range. One is from $300^{\circ} \mathrm{C}$ to $390^{\circ} \mathrm{C}$ which corresponds to the pyrolysis of the $\mathrm{H}_{3}$ pytpy $^{3+}$ cation, and the weight loss is $59.64 \%$ (Calcd. $60.14 \%$ ). The other is in the range of $390^{\circ} \mathrm{C}$ to $500^{\circ} \mathrm{C}$, and corresponds to the pyrolysis of the $\mathrm{BTC}^{3-}$. The weight loss is $39.84 \%$, consistent with the calculated value $39.58 \%$. Finally, the residue is nothing.

\subsection{Fluorescence}

The fluorescent emission spectra of $\mathbf{1}$ in the solid state are investigated at room temperature (figure 7).

Table 3. Hydrogen bond lengths $[\AA]$ and angles $\left[{ }^{\circ}\right]$ for $\mathbf{1}$.

\begin{tabular}{|c|c|c|c|c|}
\hline D-H...A & $\mathrm{d}(\mathrm{D}-\mathrm{H})$ & $\mathrm{d}(\mathrm{H} \ldots \mathrm{A})$ & $\mathrm{d}(\mathrm{D} \ldots \mathrm{A})$ & $<(\mathrm{DHA})$ \\
\hline $\mathrm{N}(1)-\mathrm{H}(1 \mathrm{~A}) \ldots \mathrm{O}(4) \# 1$ & 0.86 & 1.80 & $2.618(4)$ & 158.8 \\
\hline $\mathrm{C}(2)-\mathrm{H}(14) \ldots \mathrm{O}(5) \# 2$ & 0.93 & 1.77 & 2.6855 & 168 \\
\hline $\mathrm{C}(3)-\mathrm{H}(15) \ldots \mathrm{O}(6) \# 2$ & 0.93 & 2.48 & 3.1324 & 127 \\
\hline $\mathrm{C}(11)-\mathrm{H}(17) \ldots \mathrm{O}(6) \# 3$ & 0.93 & 2.58 & 3.1841 & 123 \\
\hline $\mathrm{C}(13)-\mathrm{H}(13 \mathrm{~A}) \ldots \mathrm{O}(1) \# 4$ & 0.93 & 1.73 & 2.6196 & 160 \\
\hline $\mathrm{C}(14)-\mathrm{H}(20) \ldots \mathrm{O}(2) \# 4$ & 0.93 & 2.47 & 3.1655 & 131 \\
\hline $\mathrm{C}(18)-\mathrm{H}(3) \ldots \mathrm{O}(2) \# 5$ & 0.93 & 2.48 & 3.3899 & 168 \\
\hline
\end{tabular}

Symmetry transformations used to generate equivalent atoms:

\#1 x, y+1, z \#2 -x, y, -1/2-z \#3 x, 1-y, 1/2+z \#4 1/2-x, -1/2+y, 1/2-z \#5 1/2-x, 1/2+y, $1 / 2-\mathrm{z}$ 


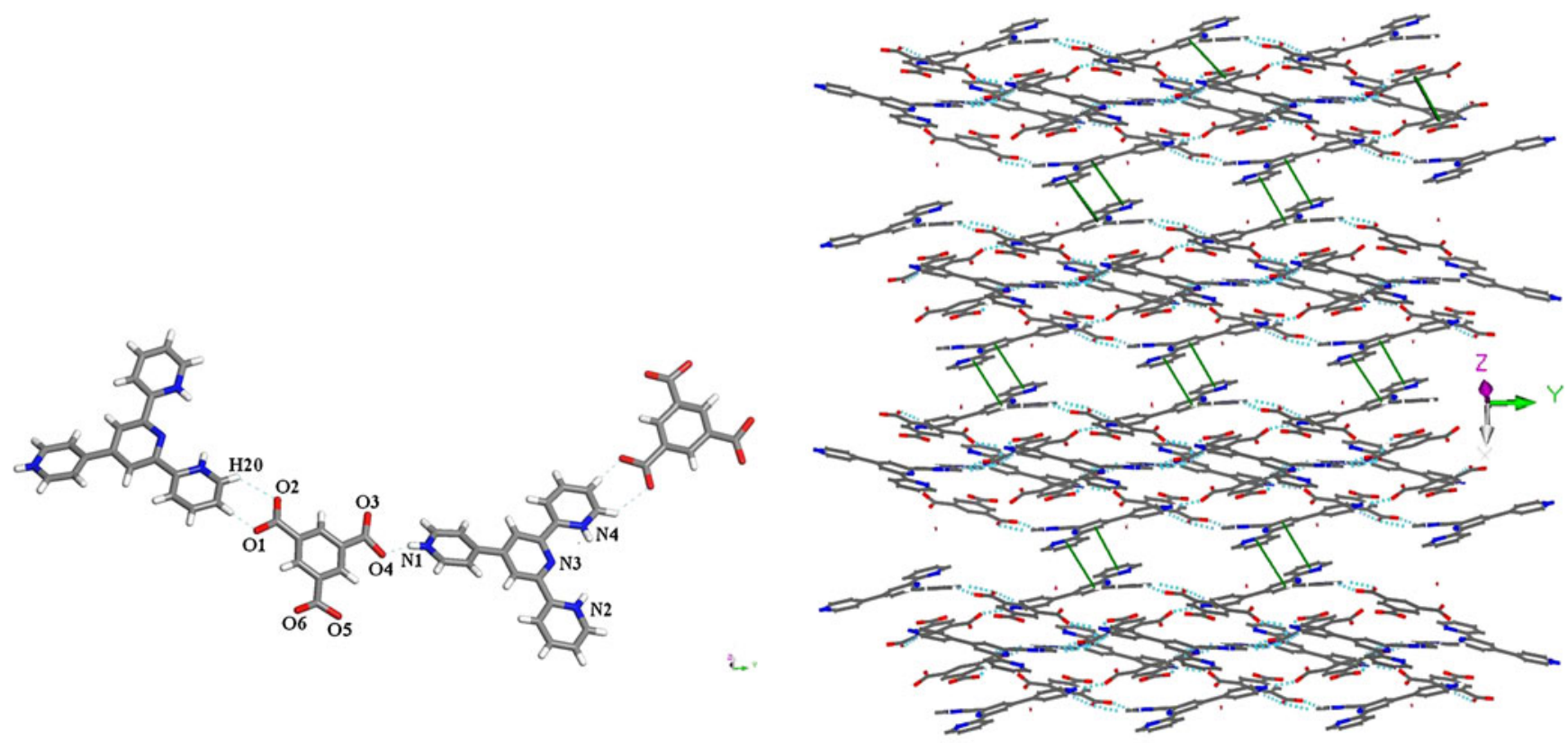

(a)

(b)

Figure 3. (a) A single helical chain. (b) 2-D six-fold helical layers in the ab plane. Hydrogen bonds are drawn as dotted light blue lines, three kinds of $\pi-\pi$ interactions are drawn as green line.

The emission bands for free pytpy is at $418 \mathrm{~nm}\left(\lambda_{\text {ex }}\right.$ $=354 \mathrm{~nm}$ ), which may be attributed to the $\pi^{*} \rightarrow \pi$ transition. Free $\mathrm{H}_{3}$ BTC displays fluorescence emission at $390 \mathrm{~nm}\left(\lambda_{\mathrm{ex}}=334 \mathrm{~nm}\right)$ with a shoulder peak at $370 \mathrm{~nm}$ attributed to the $\pi^{*} \rightarrow n$ transition. ${ }^{22,23}$ The maximum of the emission bands of $\mathbf{1}$ is located at $427 \mathrm{~nm}\left(\lambda_{\mathrm{ex}}=266 \mathrm{~nm}\right)$, with a shoulder at about
$390 \mathrm{~nm}$. The shoulder peak is obviously due to $\pi^{*} \rightarrow n$ transition of coordinated $\mathrm{BTC}^{3-}$ ligands, similarly to the emission of free $\mathrm{H}_{3}$ BTC, the main peak at $427 \mathrm{~nm}$ may be assigned to the $\pi^{*} \rightarrow \pi$ intraligand fluorescence emission of pytpy. The strongest excitation peak for $\mathbf{1}$ is at $266 \mathrm{~nm}$, a lower energy than those for the pytpy and $\mathrm{H}_{3} \mathrm{BTC}$ excitation peaks.

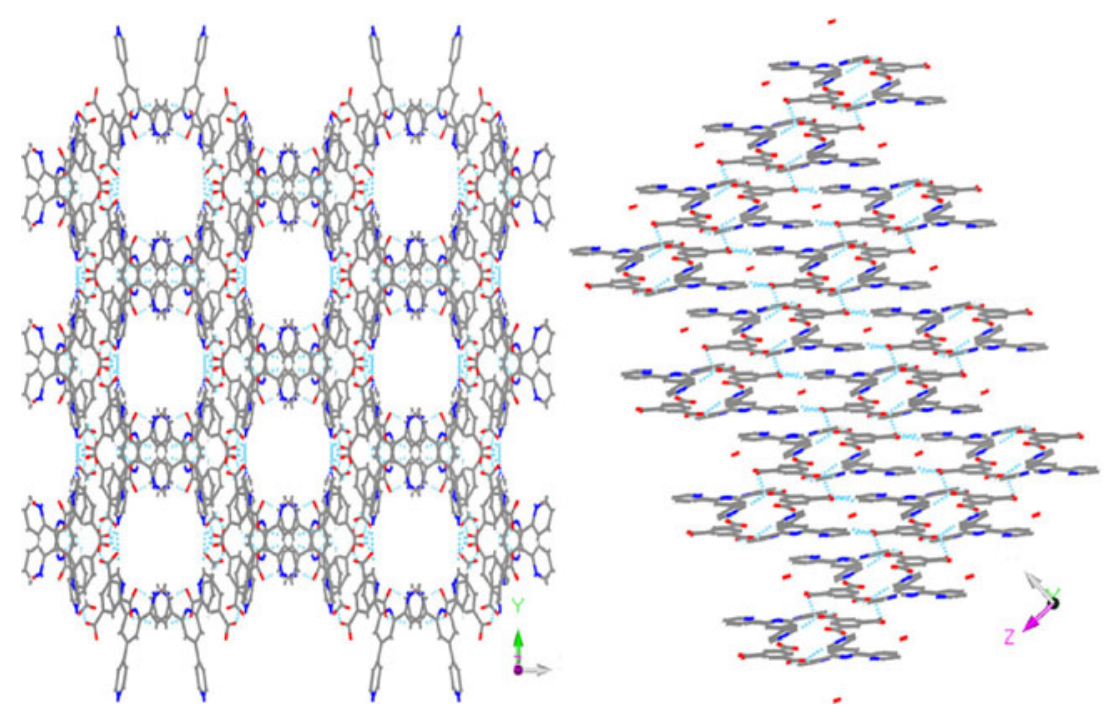

Figure 4. 3-D supramolecular network with cavities (left). The lattice water molecules occupy voids between the helical layers (right). 


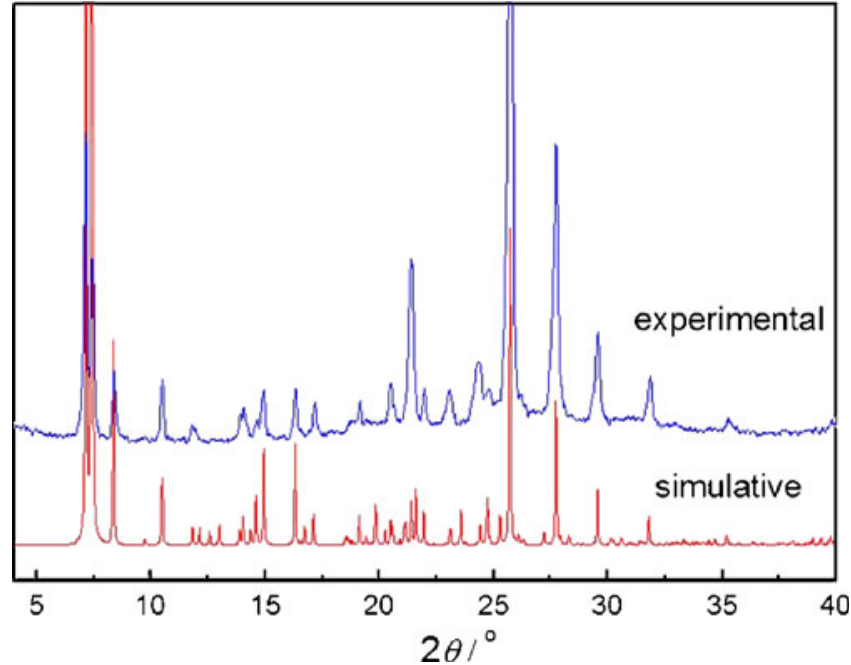

Figure 5. A plot of simulative and experimental XRD of $\mathbf{1}$.

\section{$3.4 U$-vis spectrum and quantum chemistry calculations}

The UV-visible absorption spectrum of $\mathbf{1}$ in $\mathrm{CH}_{2} \mathrm{Cl}_{2}$ $\left(1 \times 10^{-5} \mathrm{M}\right)$ and two free ligands in ethanol $(1 \times$ $\left.10^{-5} \mathrm{M}\right)$ are shown in figure 8 . Results reveal that there are three absorption bands for $\mathrm{H}_{3} \mathrm{BTC}$, centered at $227.4 \mathrm{~nm}, 234.2 \mathrm{~nm}$ and $279.5 \mathrm{~nm}$, respectively, corresponding the $\pi \rightarrow \pi *$ and $n \rightarrow \pi *$ transitions. For pytpy ligand, two absorption bands are at $240.2 \mathrm{~nm}$ and $300.8 \mathrm{~nm}$, respectively, corresponding to the $\pi \rightarrow \pi *$ transitions. In comparison with the two bands of pytpy, all the absorption bands for 1 shift toward higher energy area, centered at 224.0, 239.4 and $281.2 \mathrm{~nm}$, respectively. Result reveals that the lowest-energy absorp-

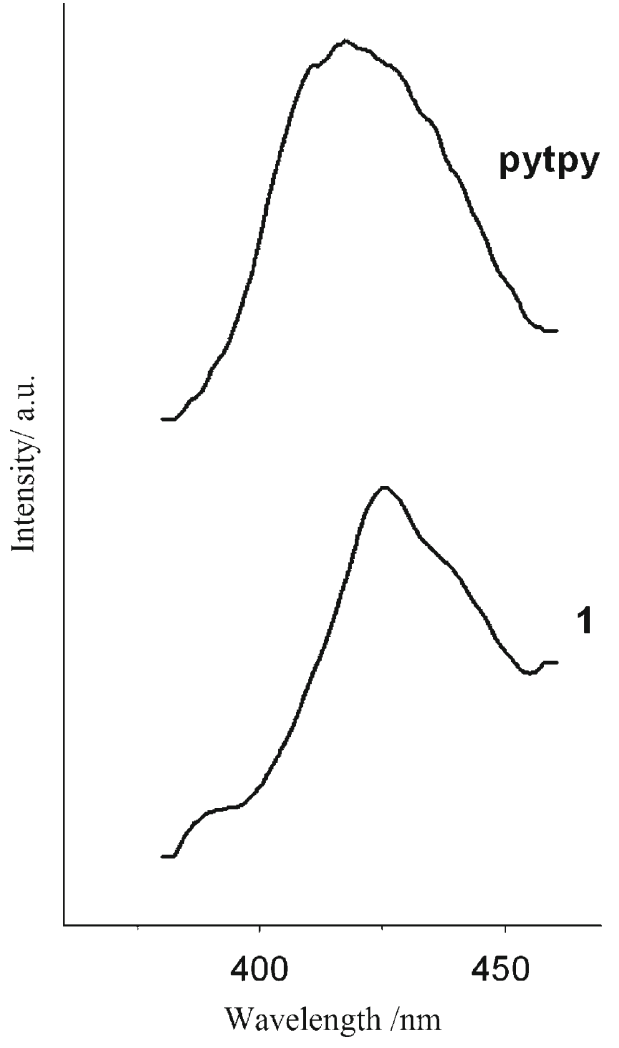

Figure 7. Solid-state emission spectra of $\mathbf{1}$ and pytpy ligand.

tion band at $281.2 \mathrm{~nm}$ is blue shift, in comparison to that of the free pytpy $(300.8 \mathrm{~nm})$, but red shift relative to $\mathrm{H}_{3} \mathrm{BTC}$. The result of UV-vis measurement will be further discussed in the follow theoretical calculation section.

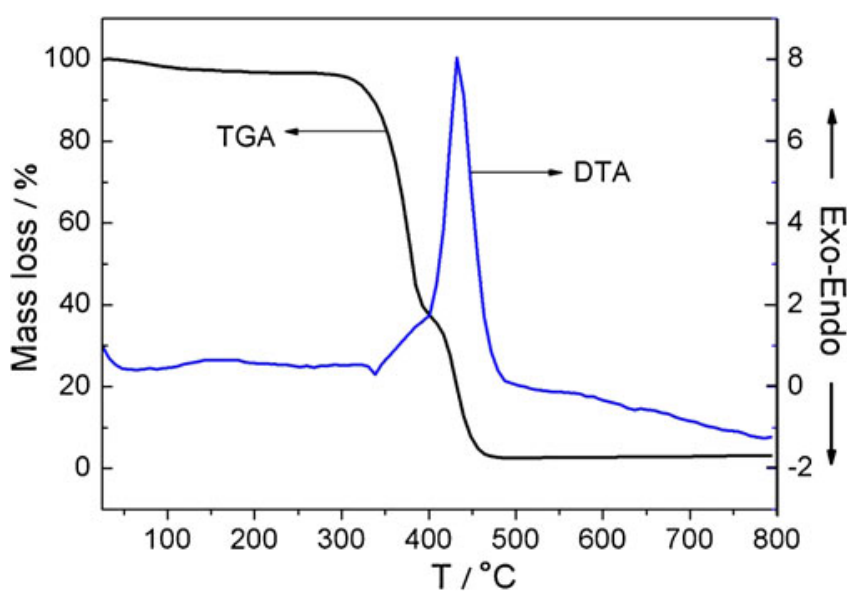

Figure 6. TG-DTA spectra of $\mathbf{1}$ in $\mathrm{N}_{2}$.

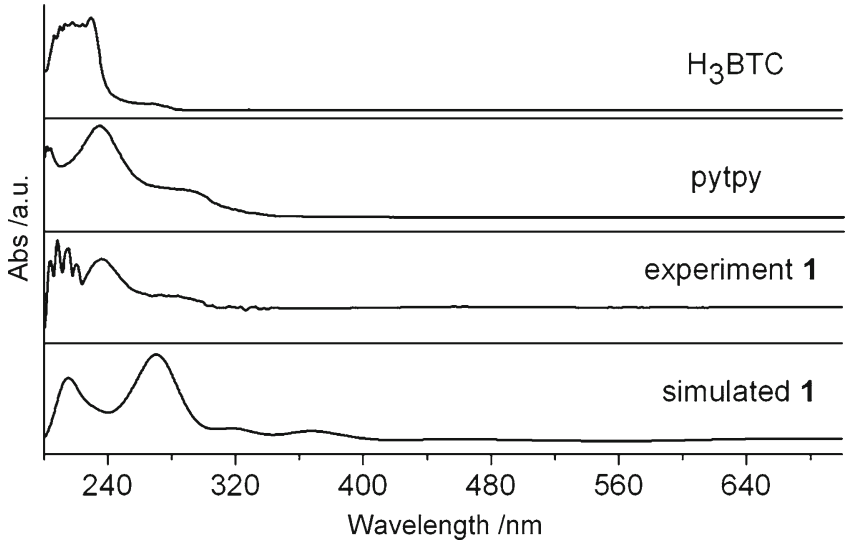

Figure 8. The UV-visible absorption spectra of $\mathbf{1}$ in $\mathrm{CH}_{2} \mathrm{Cl}_{2}\left(1 \times 10^{-5} \mathrm{M}\right)$ and two free ligands in ethanol $(1 \times$ $10^{-5} \mathrm{M}$ ), and simulated spectrum of 1 by DFT. 
Table 4. Electronic spectral data of 1 calculated with TDDFT at the B3LYP/6$31 \mathrm{G}^{*}$ level.

\begin{tabular}{|c|c|c|c|c|c|}
\hline$\lambda_{\text {cal }} / \mathrm{nm}$ & $f$ & Transition nature & Coefficient & Transition energy/eV & $\lambda_{\text {exp }} / \mathrm{nm}$ \\
\hline 213.7 & 0.1386 & H-6->L+9 (21\%) & 0.32359 & $5.8017 \mathrm{eV}$ & 224.0 \\
\hline 232.5 & 0.0611 & $\begin{array}{l}\text { H-7->L+7 }(19 \%) \\
\text { H-6->L+9 }(13 \%) \\
\text { H-8->L+7 }(12 \%)\end{array}$ & 0.31144 & $5.3335 \mathrm{eV}$ & 239.4 \\
\hline 270.2 & 0.1682 & H-16->L (57\%) & 0.53259 & $4.5887 \mathrm{eV}$ & 281.2 \\
\hline
\end{tabular}

To investigate the nature of electronic transitions, the electronic spectra of 1 was calculated using the timedependent DFT (TDDFT) approach at the B3LYP/6$31 \mathrm{G}^{*}$ starting from the experimental $\mathrm{X}$-ray structures as input geometries. Geometry optimize results show the $\mathrm{O}(4)$ in $\mathrm{BTC}^{3-}$ has captured proton $\mathrm{H}(2)$ of $\mathrm{H}_{3}$ pytpy ${ }^{3+}$, which may attribute to the distortion of carboxylate group $(\mathrm{O}(3)$ and $\mathrm{O}(4))$ relative to the central benzene ring in $\mathrm{BTC}^{3-}$. The distortion tends to shorten the distance between the oxygen atom $\mathrm{O}(4)$ and the hydrogen atom $\mathrm{H}(2)$, and further to perturb hydrogen atom $\mathrm{H}(2)$ to join with $\mathrm{N}(2)$. The strong absorption wavelength $\lambda$, oscillator strength $f$, and main configuration are listed in table 4 . There is the difference between the absorption wavelength determined experimentally and the simulated one calculated by DFT. The fundamental reason may be that the solvent effect is not considered.

The results of calculations reveal that the low-energy absorption bands center at $270.2 \mathrm{~nm}(4.5887 \mathrm{eV})$ for $\mathbf{1}$, corresponding the oscillator strength $f=$ 0.1682 , which indicate the transition is mainly due to the promotion of one-electron from (HOMO-16) to LUMO, the (HOMO-16) $\rightarrow$ LUMO promotion for $\mathbf{1}$ shows some intermolecular electron-density transfer between $\mathrm{BTC}^{3-}$ and $\mathrm{H}_{3}$ pytpy ${ }^{3+}$. The absorption band centered at $213.7 \mathrm{~nm}(5.8017 \mathrm{eV})$, oscillator strength $f=0.1386$, is mainly resulted from the (HOMO$6) \rightarrow($ LUMO+9) one-electron promotion, showing intermolecular electron-density transfer. Absorption band centered at $232.5 \mathrm{~nm}(5.3335 \mathrm{eV})$, oscillator strength $f=0.0611$, is mainly resulted from the $(\mathrm{HOMO}-7) \rightarrow(\mathrm{LUMO}+7), \quad(\mathrm{HOMO}-6) \rightarrow(\mathrm{LUMO}+9)$, $(\mathrm{HOMO}-8) \rightarrow(\mathrm{LUMO}+7)$ one-electron promotion, showing inter- and intra-molecular electron-density transfer of BTC ${ }^{3-}$ (figure 9).

So the blue shift of lowest-energy absorption band relative to pytpy and red shift relative to $\mathrm{H}_{3} \mathrm{BTC}$ may be related to the combination effect of pytpy and $\mathrm{H}_{3} \mathrm{BTC}$ molecules. It may arise from the same $n \rightarrow \pi^{*}$ and $\pi \rightarrow \pi^{*}$ transition with the $n$ orbital (HOMO located on the BTC $^{3-}$ anion, while LUMO located on the $\mathrm{H}_{3}$ pytpy ${ }^{3+}$ cation) or intermolecular charge transfer transition between $\mathrm{H}_{3}$ pytpy ${ }^{3+}$ and $\mathrm{BTC}^{3-}$ ions in 1. Frontier orbital (figure 10) was obtained by density functional theory (DFT) singlepoint calculation at the B3LYP/6-31 $\mathrm{tg}(\mathrm{d}, \mathrm{p})$ level. The orbital energy analysis shows $\mathrm{E}_{\text {Но }}$ O and $\mathrm{E}_{L U M O}$ values are $-4.46 \mathrm{eV}$ and $-3.22 \mathrm{eV}$ for $\mathbf{1}$, respectively, corresponding to HOMO-LUMO energy gap $E_{g}=1.24 \mathrm{eV}$. The HOMO-LUMO energy gap has been used as a simple indicator of kinetic stability. ${ }^{24,25}$ A small HOMO-LUMO energy gap (1.24 eV) implies low kinetic stability and high chemical reactivity. Also, lower energetic HOMO-LUMO gap is indicative of the existence of a certain degree of conjugation, which is caused by the $\pi$-stacking structures in $\mathbf{1}$ between pyri-
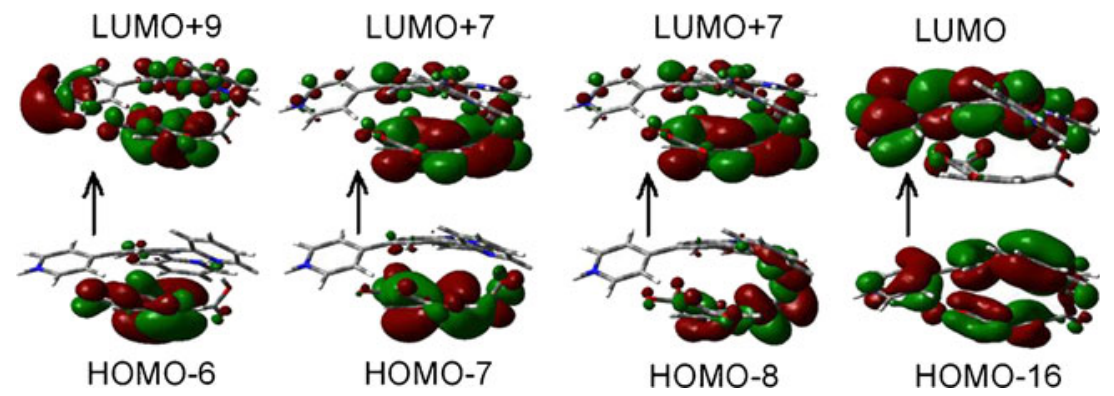

Figure 9. Electron-density transfer, responding absorption bands calculated by DFT, respectively. 


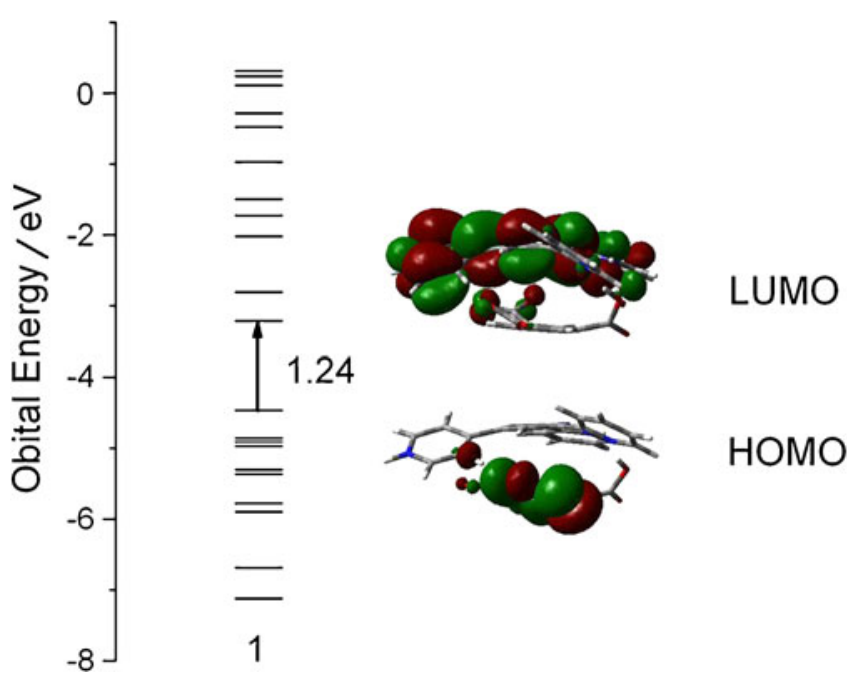

Figure 10. Calculated HOMO (bottom) and LUMO (top) orbits (B3LYP/6-31t g (d,p)) for $\mathbf{1}$.

dine rings and benzene rings. The HOMO is mainly situated in the $\mathrm{BTC}^{3-}$ donor moiety, while LUMO is localized on the $\mathrm{H}_{3}$ pytpy ${ }^{3+}$ segment.

\section{Conclusion}

In summary, a new pytpy/ $\mathrm{H}_{3} \mathrm{BTC}$ adduct $\mathbf{1}$ has been synthesized in solvothermal technique. Adduct units of $\mathbf{1}$ are connected with each other to generate 1-D sixfold helical double chain along the $b$-axis and further to 2-D six-fold helical layers in the $a b$ plane, finally extend into a 3-D supramolecular network with cavities through hydrogen bonds and the offset face to face $\pi-\pi$ interactions between pyridine rings and benzene rings, together with the face to face $\pi-\pi$ interactions between two benzene rings. The dissociative water molecules localize on the voids between the layers. Results of photophysical experiments are discussed and compared with those of DFT calculations. The small HOMOLUMO energy gap (1.24 eV) indicates low kinetic stability and high chemical reactivity of the compound $\mathbf{1}$. So in the next step, we plan to synthesize the compounds contains rare earth metal ions and adduct $\mathbf{1}$ to exploit their properties as well as their applications in the optical materials.

\section{Supplementary information}

The electronic supporting information can be seen in www.ias.ac.in/chemsci.

\section{Acknowledgements}

The authors are grateful to The National Natural Science Foundation of China for financial support, Open Fund of Jiangsu Key Laboratory for Chemistry of Low-dimensional Materials and Huaian Scientific and technological support industrial projects (Projects Nos. 20671038, JSKC09068, HAG09054-12 and 10KJD150001).

\section{References}

1. Beves J E, Constable E C, Housecroft C E, Neuburger $\mathrm{M}$ and Schaffner S 2008 Cryst. Eng. Comm. 10344

2. Shi W J, Hou L, Li D and Yin Y G 2007 Inorg. Chim. Acta 360588

3. López J P, Kraus W, Reck G, Thünemann A and Kurth D G 2005 Inorg. Chem. Commun. 8281

4. Zhang S S, Zhan S Z, Li M, Peng R and Li D 2007 Inorg. Chem. 464365

5. Hou L, Li D, Shi W J, Yin Y G and Ng S W 2005 Inorg. Chem. 447825

6. Li X H, Lei X X and Wang S 2005 Acta Cryst. E61 o1802

7. Yaghi O M and Li H L 1996 J. Am. Chem. Soc. 118295

8. Carlson C N, Kuehl C J, Da Re R E, Veauthier J M, Schelter E J, Milligan A E, Scott B L, Bauer E D, Thompson J D, Morris D E and John K D 2006 J. Am. Chem. Soc. 1287230

9. Wang P S, Moorefield C N, Panzer M and Newkome G R 2005 Chem. Commun. 2005465

10. Beves J E, Constable E C, Decurtins S, Dunphy E L, Housecroft C E, Keene T D, Neuburger M, Schaffner S and Zampese J A 2009 Cryst. Eng. Commun. 112406

11. Indumathy R, Radhik S, Kanthimathi M, Weyhermuller T and Nair B U J 2007 Inorg. Biochem. 101434

12. Hayami S, Hashiguchi K, Juhász G, Ohba M, Okawa H, Maeda Y, Kato K, Osaka K, Takata M and Inoue K 2004 Inorg. Chem. 434124

13. Beves J E, Bray D J, Clegg J K, Constable E C, Housecroft C E, Jolliffe K A, Kepert C J, Lindoy L F, Neuburger M, Price D J, Schaffner S and Schaper F 2008 Inorg. Chim. Acta 3612582

14. Granifo J, M. Garland T and Baggio R 2004 Inorg. Chem. Commun. 777

15. Wang B C, Wu Q R, Hu H M, Chen X L, Yang Z H, Shangguan Y Q, Yang M L and Xue G L 2010 Cryst. Eng. Commun. 12485

16. Wang B C, Chen X L, Hu H M, Yao H L and Xue G L 2009 Inorg. Chem. Comm. 12856

17. Shattock T R, Vishweshwar P, Wang Z Q and Zaworotko M J 2005 Cryst. Growth Des. 52046

18. Becke A D J 1993 Chem. Phys. 985648

19. Lee C, Yang W and Par R G 1988 Phys. Rev. B 37785

20. Frisch M J, Trucks G W, Schlegel H B, Scuseria G E, Robb M A, Cheeseman J R, Montgomery Jr J A, Vreven T, Kudin K N, Burant J C, Millam J M, Iyengar S S, Tomasi J, Barone V, Mennucci B, Ossi M, Scalmani G, Rega N, Petersson G A, Nakatsuji H, Hada M, Ehara M., 
Toyota K, Fukuda R, Hasegawa J, Ishida M, Nakajima T, Honda Y, Kitao O, Nakai H, Klene M, Li X, Knox J E, Ratchian H H P, Cross J B, Adamo C, Aramillo J J, Gomperts R, Stratmann R E, Yazyev O, Austin A J, Cammi R, Pomelli C, Ochterski J W, Ayala P Y, Morokuma K, Voth G A, Salvador P, Dannenberg J J, Zakrzewski V G, Dapprich S, Daniels A D, Strain M C, Farkas O, Malick D K, Rabuck A D, Raghavachari K, Foresman J B, Ortiz J V, Cui Q, Baboul A G, Clifford S, Cioslowski J, Tefanov B B, Liu G, Liashenko A, Piskorz P, Komaromi I, Martin R L, Fox D J, Keith T, Al-Laham M A, Peng C Y, Nanayakkara A, Challacombe M, Gill P M W, Johnson B, Chen W, Wong M W, Gonzalez C and
Pople J A 2003 Gaussian 03, Revision B.05 (Pittsburgh, PA: Gaussian, Inc)

21. Sheldrick G M 1997 SHELXS-97 and SHELXL-97. Program of Crystal Structure Refinement (Germany: University of Göttingen)

22. Chen W, Wang J Y, Chen C, Yue Q, Yuan H M, Chen J S and Wang S N 2003 Inorg. Chem. 42944

23. Shi X, Hu G S, Frang Q R, Wu G, Tian G, Wang R W, Zhang D L, Xue M and Qiu S L 2004 Eur. J. Inorg. Chem. 2004185

24. Kim K H, Han Y K and Jung J 2005 Theor. Chem. Acc. 113233

25. Aihara J 1999 J. Phys. Chem. A103 7487 